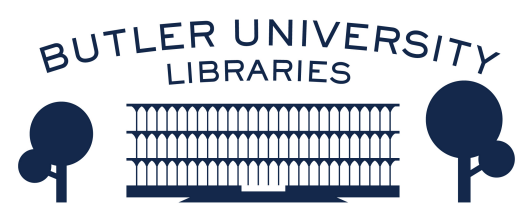

Journal of Hindu-Christian Studies

Volume 24

Article 8

November 2011

\title{
A Literary Hindu-Christian Dialogue A Century Ago: Still Actual?
}

Klaus K. Klostermaier

Follow this and additional works at: https://digitalcommons.butler.edu/jhcs

Part of the Religion Commons

\section{Recommended Citation}

Klostermaier, Klaus K. (2011) "A Literary Hindu-Christian Dialogue A Century Ago: Still Actual?," Journal of Hindu-Christian Studies: Vol. 24, Article 8.

Available at: https://doi.org/10.7825/2164-6279.1485

The Journal of Hindu-Christian Studies is a publication of the Society for Hindu-Christian Studies. The digital version is made available by Digital Commons @ Butler University. For questions about the Journal or the Society, please contact cbauman@butler.edu. For more information about Digital Commons @ Butler University, please contact digitalscholarship@butler.edu. 


\title{
A LITERARY HINDU-CHRISTIAN DIALOGUE A CENTURY AGO: STILL ACTUAL?
}

\author{
Klaus K. Klostermaier \\ University of Manitoba
}

RE-READING Alkondavilli Govindācārya The Divine Wisdom of the Drāvida Saints, Madras: C. N. Press, 1902, XXIII + 216 pages.

A preliminary note: This is not a 'book review' as this is usually understood; it would make little sense to write one after over a century of the first publication of the work. It is an invitation to re-discover a reputable Hindu scholar who was eager to find in Christianity parallels to his own faith-tradition. His very choice of topics is intriguing. The range of Christian literature referred to and quoted from is amazing; I believe it is without parallel. The fact that the book was reprinted a century later and is still highly regarded by contemporary Śrīvaiṣnavas says something, too. This brief report is meant to encourage Christian scholars interested in Hindu-Christian dialogue to look into the work in order to see what spirituallyminded Hindus find attractive about Christianity.

An introductory explanation: Professor M. Yamunācārya of Mysore University, one of the few Hindu scholars actively interested in HinduChristian dialogue in the mid-twentieth century, ${ }^{1}$ presented me in 1969, after my Ph.D. thesis defense, ${ }^{2}$ with a small volume, The Divine Wisdom of the Drāviḍa Saints, written by his grandfather Alkondavilli Govindācārya, whom he described as his guru and early spiritual guide. The book was published in 1902 in Madras, and I had considered it a precious relic:
A rare book, I thought! I was surprised to discover through Google that there were several recent reprints of it (one from Madras in 1998) and even an on-line version. It appears that Alkondavilli Govindācārya is still highly revered by the Śrīvaiṣnava community in India, and his memory is very much alive. His books ${ }^{3}$ count among the most popular reading of scholarly Śrīvaișnavas.

I have not seen any other work written by a Hindu scholar with as many and as diverse references to - and quotes from - Christian sources. Alkondavilli Govindācārya seemed eager to demonstrate to his readership that there was a basic agreement between the religion of the Alvars and Christianity.

The work itself: In the Introduction Alkondavilli tells us that his book consists of selected (translated) extracts from a ten-volume Telugu translation of Piran Pillai's Bhāgavata Visaya, a Manipravala ${ }^{4}$ commentary on Nammālvār's Tiruvāymo $\overline{r i}{ }^{5}$ The exact reference to the relevant section of the Bhāgavata Vișaya is given at the end of each topic and the sequence of topics follows the order in the Bhāvagata Viṣaya. Alkondavilli also respectfully refers numerous times to his own guru Yogi Śrī Pārthasārathi. He begins his Introduction with a quote from one of Pārthasārathi's books ("Love makes the Saint, Wisdom the sage") and ends the work with one of Pārthasārathi's hymns to Śrī.

Klaus K. Klostermaier, Fellow of the Royal Society of Canada, Distinguished Professor Emeritus, University of Manitoba, author of numerous books and articles on Hinduism (e.g. A Survey of Hinduism, SUNY 3rd edition 2007, Hinduism: A Short Introduction, Oneworld: Oxford 4th printing 2008. Engaged in Hindu-Christian dialogue since the 1960s (Christian and Hindu in Vrindaban, SCM London 1971) he was also a frequent contributor to the Hindu-Christian Studies Bulletin. One of his major interests had been the Science-Religion dialogue. He team-taught graduate courses in this area with science-faculty and was the recipient of a Templeton Foundation Course Award (1995). Among his publications in this area is The Nature of Nature: Explorations in Science, Philosophy and Religion, Theosophical Publishing House: Adyar, 2004. 
Alkondavilli emphasizes that - contrary to the opinion of F. Lorinser, who had maintained that the Bhagavadgitā was written under the influence of Christian ideas - the sublime theism of the Hindus was indigenous to India and by far predates Christianity: "We must warn our Christian Brethren against falling into the error of supposing, that the sublime Doctrines of Faith, Grace, Love, Salvation by mediation, and by atonement, Motherhood of God, Image Worship, Incarnation-Doctrine etc. held by ancient Saints of India, must have been borrowed from Christian Scriptures: Lord Kṛ̣ṇa antedates Jesus by nearly three thousand years." ${ }^{6}$ And: "Saint Nammālvār was born just fortythree days after the Ascension of Krṣna."

Alkondavilli takes exception to those Western scholars who considered Śhankara's Advaita the apex of Indian thought: "It is a sorry fact that Orientalists like Edward Gough, M.A. and Divines like Rev. C. Cooper have persistently represented to the world, in their Philosophy of the Upanishads, the cold and inert nature of Brahman as taught in the Upanisads. They have persistently ignored to hear Rāmānuja, nor have they discovered for themselves that their own Christian demand for a righteous God is fully met by such passages as apahata-papma etc. and God as Love by such passages as ānanda brahmeti vyājanāt etc."

Alkondavilli obviously did extensive and systematic reading in Christian literature, classical as well as contemporary: much more than the average Christian reader of his time would have done! Since the book is meant to describe the "Divine wisdom of the Drāvida Saints" it presents in the main body free translations from the Bhāgavata Viṣaya and offers what Alkondavilli considered Christian parallels in extensive footnotes, which often cover more than half a page! The very choice of titles to the chapters is intriguing: the juxtaposition of Hindu and Christian sources is certainly in and by itself a dialogue, even if the term had not been in use then.

There are over 30 references to the Bible, most of them to the New Testament: Alkondavilli treats the Bible as a revealed book and uses quotes from it as confirmation for the teachings of the Alvars. Thus in Topic 32 "The victory of faith" he relates in the main-body the story of the great faith of Hindu saint Pundarika and refers in a footnote to Matthew VII, 7 ("Ask, and it shall be given to you") and several other places in the Gospels, where Jesus exhorts his disciples to have faith.

Thomas a Kempis' Imitatio Christi is referred to ten times: In footnotes to Topic 18: "God as Love contrasted with God as Supreme", Topic 40: "Cultivating love to God, is in itself an end", Topic 44 "Intoxicated with Love of God", Topic 59 "What constitutes fitness and unfitness, to praise God", Topic 65 "Love of God unto death", Topic 88 "Purity (Sincerity) in the Love of God", Topic 133 "The Delirium of love to God", Topic 140 "God's visits and desertions, causing Saints transports of joy and pangs of grief (respectively)", Topic 155 "Inordinate affection for wife and children," and topic 164 "Service to God, the Highest End of Man."

Madame Guyon is cited with 17 references to her poetry. She is quoted as a Christian parallel to the Alvars in Topic 19 "God's Grace Alone can crown personal effort", Topic 20 "What does absence of God signify", Topic 43 "Pride and Humility contrasted", Topic 44 "Intoxicated with love of God" parallel to Thomas a Kempis, Topic 50 "One moment of bereavement from God, is an age", Topic 68 "What is not God's is no use being ours", Topic 70 "The tenderness of saint's hearts", Topic 72 "Morbid love of lucre", Topic 103 "Saints are Gods on earth", Topic 106 "Secrets between God and His Saints, Topic 111 "The perpetual growth of Saints' love for God", Topic 112 "The bewitching beauty of God", Topic 114 "A Love comparison between two Saints". ${ }^{8}$ Topic 130: "The Perversity of our free will arresting or resisting the free operation of God's grace", Topic 132 "The Delirium of Love to God", Topic 167 "Insatiable love to God", and Topic 169 "A moment's Absence of God is an age of pang to lovelorn Saints."

Butler's Lives of Saints is referred to 10 times: Christian hagiographies are paralleled with Hindu saints. The Theologia Germanica is quoted three times: under Topic 1 "What is True 
Renunciation?", Topic 2 "The Natural Relation between God and Souls as between Lord and liege or Creator and creature," and Topic 5 "Loving Service to God is the 'All' of Saints. Fr. Rodriguez' multivolume Christian and Religious Perfection is quoted in Topic 144 "Nothing of, our own would God have but obedience on our side."

There are two references to Cardinal Newman under Topic 124 "God manifest in images" and Topic 182 "Salvation sure under Mother Universal". There is one reference each to St. Augustine 's City of God (Topic 78: "The Power of Monotheistic Faith"), F. Bossuet, (Topic 40: "Cultivating love to God is in itself an end"), Frederic C. Oakelen., Rev. Rutherford, Rev. E, J., Fripps, A. Wells, and Johannes Tauler (Topic 2: "The Natural Relation between God and Souls..."). F. W. Faber's Creator and Creation must have been a popular work at the time: it is referred to eleven times.

The most quoted source is Francis de Sales' Treatise on the Love of God. ${ }^{9}$ Alkondavilli says in his introduction that he took over from Francis de Sales the plan for his work. ${ }^{10} \mathrm{He}$ quotes him more than forty times in the body of the work. In a footnote to Topic 10 "The forgetting God and re-collecting Him" he quotes an entire paragraph from the Treatise. Two lengthy quotes are found accompanying Topic 18 "God as Love contrasted with God as Supreme etc.". Topic 26 "God is bent on saving us" also has a lengthy reference to the Treatise. The same in connection with topic 28 "God's Grace is free." Several quotes from the same source support Topic 37: "The Inordinate thirst of saints for God, or love to God insatiable." With Topic 42 "God desires our heart" there is another reference to de Sales. A very lengthy extract from de Sales is quoted in connection with Topic 45: "The conditions of salvation illustrated." Topic 52 "The prodigality of God's beauty" also has a reference to him. Similarly Topic 54 "Overwhelming Divine ecstasy jeopardizing existence." Topic 64 "The efficacy of holy men's foot-dust" has two references to Francis de Sales. A number of quotes from $A$ Treatise are illustrating Topic 77 "The cooperation of God's free grace and man's free will." Topic 87 "The depth of God's redeeming love" is also illustrated by a quote from the same. Topic 91 "God's specific presence in forms" also includes a quote from the Treatise. Topic 112 "The bewitching beauty of God" also has a reference to this work. Topic 128 "Our free-will inclining to God's grace is itself an act of His grace" is also illustrated with a de Sales quote. So is Topic 130 "The perversity of our free-will resisting the free operations of God's grace." Topic 132 "The delirium of love to God'" is again illustrated with a quote from de Sales. So is Topic 146 "Implicit obedience and faith to masters, works miracles." Topic 156 "Divine service-three kinds" has a reference to him as well. The last reference to Francis de Sales occurs in connection with Topic 178 "Authoritative teaching alone carries weight."

Alkondavilli appears to be in complete agreement with Francis de Sales and sees his writings to be an exact parallel to the teachings of Saint Nammālvār. ${ }^{11}$ While accepting de Sales as a promoter of genuine bhakti in Christianity, Alkondavilli however insists on the priority of the 'Divine Wisdom of Drāviḍa Saints' in this regard. Assuming, as pointed out, that Nammālvār lived three thousand years before Jesus, it was the Alvar who first taught "that Grace of God alone is the sole means of salvation", a doctrine "somewhat hazily taught by Jesus, or Augustine after him, or the Muslim Sufi."12

While apparently considering Christianity as one religion - he quotes Catholic and Protestant sources side by side - he does emphasize the plurality of faiths within Hinduism, repudiating Śankara's Advaita with the traditional arguments of Śrīvaișnavas. Some pages betray quite emphatic Śrivaiṣnava sectarianism: Under Topic 66 "Martyrdom" he describes Śaiva intolerance and the torture of a Vaisnava saint at the hands of a Śaiva king: " Kuratthāḷār, the immediate disciple and lover of Rāmānuja, was a martyr to the Cause of Vaisnavism. Krimikantha-Chola, the reigning prince at the time of the Chola Kingdom, was a bigotted Śaiva. Like Mahomet's followers, converting people by their sword, he had undertaken a crusade of religious persecution, in the course of which he forcibly 
compelled every one to sign a bull he had proclaimed, to the effect that there was no other God but Siva." ${ }^{13}$ He then relates the well-known story of Kuratthar's eyes being plucked out, when he refused to sign, and of Rāmānuja's distress and prayer that restored his eyesight.

Under Topic 149 "The Old Law and the New Law, or the Law of Works and of Faith" coming back to the rule of Krimikantha Chola Alkondavilli relates how Rāmānuja resorted to a Vedic sacrifice to kill this ' Viṣnu-hater': " Rāmānuja resolved on bringing about his death by performing a sacrifice, using spells and incantations invoking Lord Venkateșvara of Holy Tirupati for the purpose. When two or three days had elapsed, a stinking smell came from the sacrificial fire as if hair was burning and he at once said: 'Stop the ceremony, the heretic is dead."'14

In Topic 100 "The story of the mission of the Buddha" he shows his contempt for Buddhism. In one of the longest sections of the book, he retells the well-known Vaiṣnava version of "the avatara of Buddha as a mask put on by Viṣnu in order to sow the seeds of doubt, dissention and heresy amongst unbelievers (as a chastisement for their folly, and subsequent redemption.)" ${ }^{15}$

Apart from one reference to Sufism, Islam is mentioned only once, in a negative context. This is quite surprising, considering the massive presence of Muslims in India at the time of writing.

Reflecting on the juxtapositions of Hindu and Christian texts, I began to ask myself, how representative of Christianity would the authors be considered today, whom Alkondavilli quoted as parallel spiritual authorities? Apart from the fact that the denominational frontiers within Christianity were always much more pronounced than he had realized and that there always was considerable debate among Christians about the meaning of the Scriptures quoted by him, I wonder how many Christians would identify their own beliefs with the writings that Alkondavilli drew from. How many Catholics today would read - or practice the Imitatio Christi or the Traite sur l'amour de Dieu? How many Protestants, Pentecostals,
Baptists etc. would consider Madame Guyon or Rene Pascal as representing their faith? Similarly, how many Alkondavillis could we find among Hindus today, who would peruse and appropriate the writings of so many Christian spiritual writers?

Obviously this is not merely a matter of contemporaneity: Alkondavilli noted in his Introduction that his approach - even in 1902 was considered somewhat out of tune with the times: "This work contains precious pearls of truth, despite the present fast-growing westernized generation's tendency to depreciate their worth, because of want of serious study, examination and reflection. This tendency, to tear oneself from the past is dangerous inasmuch as one looses his moorings and drifts in a sea of bewildering doctrines of all kinds." 16

Among the motives that prompted him to write the book he mentions that he wanted "to bring to light a lot of 'Old Spiritual Sayings' lying hidden in unread and little understood books, and which are therefore being forgotten by the present generation."17 And: "Another motive actuating us is our wish to stem the tide of materialism which by Western thought and Western habits (respectively) have unfortunately contributed to upset the minds of Indian youth, and the spiritual barrenness which it is producing by the pure secular modes of education pursued in this Country." 18

Alkondavilli could not foresee the tremendous renaissance of Hinduism in the hundred years since. Not all of it would have found his approval. The majority of new Hindu movements do not take their inspiration from the Alvars and from Rāmānuja. However, Śrīvaiṣnavism is quite alive and a saint, like the late Swami Cidananda from the Divine Life Movement (also a participant at the above mentioned Ootacamund meeting), or Prof. Yamunacharya, for that purpose, could be cited as teachers in the same spirit. While "the tide of materialism" that Alkondavilli noticed in his own time has become a worldwide tsunami of a dimension that Alkondavilli could not have imagined, there are beacons of spirituality and selflessness shining also in our age.

Both in India and in the West some 
contemporaries do appreciate the "Wisdom of the Drāvida Saints" and try to find parallels between Śrīvaiṣnavism and Christianity. Alkondavilli would probably have been delighted by a recent study like John Carman and Vasudha Narayana's The Tamil Veda: Pillan's Interpretation of the Tiruvaimoli ${ }^{19}$ - a cooperative venture between a Śrīvaiṣnava and a Christian scholar. Or by Francis Clooney's Beyond Compare: St. Francis de Sales and Śrī Vedānta Deśika on Loving Surrender to God ${ }^{20}$ focusing on the "Treatise on the Love of God" that he had considered so highly.

The very fact that Alkondavilli's Wisdom of Drāviḍa Saints has been kept in print in our age and time and that studies like CarmanNarayana's and Clooney's are found academically acceptable shows that the sense for what Alkondavilli had considered the essentials in religion - Bhakti or the love of God - has not died out and that the "Old Spiritual Sayings" East and West still find a readership in the 21st century.

\section{Notes}

1 Prof. Yamunācārya was one of seven Hindu participants at a memorable dialogue meeting in 1966 at Ootacamund/Nilgiris, organized by Prof. Douglas Steere from the Hartford Foundation.

2 Prof. Yamunācārya had been appointed outside examiner for my University of Bombay (now: Mumbai) Ph.D. thesis in Ancient Indian History and Culture in 1969. At the time he was suffering from a heart condition, which forbade him to travel to Bombay. The University of Bombay generously funded a trip to Mysore for my advisor, Prof. L. B. Keny and me, to conduct the examination at Mysore University. Prof. Yamunācārya generously offered hospitality in his home to both Prof. Keny and me.

${ }^{3}$ Besides The Divine Wisdom of the Drāvida Saints, Alkondavilli Govindācārya also published The Holy Lives of the Ālvārs, or The Drāviḍa Saints and an English translation of Rāmānuja's Gītābhāṣhyam.

${ }^{4}$ Manipravāla is a literary language consisting of a mixture of Sanskrit (mani=diamonds) and Tamil ( pravāla $=$ corals) vocabulary.

${ }^{5}$ K. Ayappa Paniker, Mediaeval Indian Literature: An Anthology (Sahitya Akademi Delhi 1997, Vol. 2, p. 518) writes: " Rāmānuja appointed Thirukkuukai Piran Pillai, his son, and later his 'spiritual son' to write the commentary on Nammāḷār's poems." J.
Carman and V. Narayana, in The Tamil Veda (University of Chicago Press, 1989, p. XXI) describe Piran Pillai as Rāmānuja's "cousin and disciple" who wrote the work between 1100 and $1150 \mathrm{CE}$.

${ }^{6}$ P. XXI Alkondavilli provides evidence for his assertion.

${ }^{7}$ P. XXII. While the dates of the Mahābhārata War, the life of Kṛnna and of Nammālvār are still the matter of scholarly controversy, there is no doubt that the Kṛnna-tradition pre-dates Christianity.

8 The comparison is between Nammālvār and Tirumangalālvār.

${ }^{9}$ Alkondavilli refers to an English translation of the work that was not accessible to me. The treatise is contained (in the original French version of 1616) in Oevres de Saint Francois de Sales, ed. by Andre Ravier, Edition Gallimard, Paris 1669.

${ }^{10}$ P. IV, Note 1.

${ }^{11}$ P. XIV.

${ }^{12}$ P. 78.

${ }^{13}$ P. 78.

${ }^{14}$ P. 166.

${ }^{15}$ Pp. $115-117$.

${ }^{16} \mathrm{P}$. VII.

${ }^{17}$ ibid.

${ }^{18}$ ibid.

19 John Carman and Vasudha Narayana, The Tamil Veda: Pillan's Interpretation of the Tiruvaymoli, The University of Chicago Press, 1989.

20 Francis Clooney SJ, who calls himself a 'comparative theologian', has come out with what could be considered a kind of parallel to Alkondavilli's work: Beyond Compare: St. Francis de Sales and Śrī Vedānta Deśika on Loving Surrender to God, Georgetown University Press, Washington DC, 2008. 